\title{
VPLYV KVALITY MANAŽMENTU NA ÚŽITOK KULTÚRNYCH EKOSYSTÉMOVÝCH SLUŽIEB
}

\author{
Martina Turanovičová, Zdenka Rózová
}

\begin{abstract}
The city is a lively organism and is a living space for many people. The level of urban green spaces affects the quality of life of its inhabitants. Spaces provide people many benefits that we define as ecosystem services. We engage in cultural ecosystem services, specifically recreation. We evaluate the vegetation areas in terms of their quality and the level of provision of human benefits. We evaluate these components: vegetation quality, space design, environmental quality, management and equipment. In the paper, we evaluate the management of the vegetation area on the Chrenová settlement in Nitra. The quality of management of vegetation areas directly affects the provision of cultural ecosystem services. The retained areas provide a suitable recreational area for the population. In this contribution, we would like to point out a new methodical approach to assessing the extent of management benefits for cultural ecosystem services, namely recreation on the chosen vegetation area of the settlement Chrenová.
\end{abstract}

Keywords: management, urban green spaces, recreation

\section{Úvod}

Kultúrne ekosystémové služby (KES) sú ekosystémy priamo zodpovedné za kvalitu života $\mathrm{v}$ mestských systémoch a sú priamo využívané a oceňované obyvatel'mi a návštevníkmi mestských systémov. Sú o pochopení spôsobu života l'udí. Odrážajú a tvoria hodnoty a dejiny, ktoré l'udia zdiel'ajú, praktiky a činnosti, ktorými sa l'udia zaoberajú a miesta, kde bývajú (Chan, 2011, Plieninger, 2013). Podl'a Miléniového hodnotenia ekosystémov majú kategórie: duchovné a náboženské, estetické hodnoty, kultúrna diverzita, rekreácia a turizmus, znalostné systémy a vzdelávacie hodnoty (Maes et al., 2013). Podrobne sa venujeme kategórii rekreácia.

Vegetačné plochy sú dôležitým prvkom zelenej infraštruktúry mesta a poskytujú širokú škálu ekosystémových služieb hlavne kultúrnych služieb, ako je rekreácia a regenerácia síl obyvatel’ov. Význam mestskej vegetácie a vol'ne žijúcich živočíchov má vel'ký význam (Dover, 2015).

Verejné priestranstvo by malo byt' miesto, ktoré má mat' funkčnú zeleň, bezpečný mobiliár a chodníčky, príjemné osvetlenie, priestor na relax a jednoduchý šport, miesto pre hry detí a mládeže. Pozitívom verejného 
priestranstva je prítomnost' vegetácie v mestskom prostredí a jej dostupnost'. Striedanie zatienených a slnečných miest vytvára možnosti rekreácie počas celého roka a umožňuje absolvovat' základné l’udské potreby v kultúrnom a čistom priestore na to určenom (Ladlle et al., 2013).

Verejný priestor by mal spíňat' niekol'ko základných atribútov. Patrí sem využitel'nost', vhodnost' $\mathrm{k}$ rôznym činnostiam, hlavne k pobytovým funkciám. Konečným užívatel'om dobrého verejného priestoru sa stávajú l'udia, ktorí sa v ňom zdržiavajú (Horká, Drochytková, Nepustilová, 2014).

Urbánna vegetácia je významným sprírodňujúcim a estetickým prvkom l’udských sídiel. Tu sa uplatňujú jej ekologické, sociálne a z časti tiež hospodárske funkcie. Esteticky a kompozične dotvára krajinný obraz sídla a pôsobí pozitívne tiež na fyziologický a psychický stav človeka (Supuka a kol., 2004).

Na základe uvedených skutočností sme vytvorili metodický prístup na hodnotenie kvality vegetačných plôch a ich mieru úžitku pre rekreáciu obyvatel'ov. Tento prístup nadväzuje na existujúce metódy hodnotenia ekosystémových služieb (ES) (Piscová a kol., 2018), ktoré sú riešené vo vel'kých mierkach (celé územie Slovenska, regióny apod.). My riešime územia na lokálnej úrovni (1:500 až 1:1 000). Hodnotenie je podrobnejšie a výsledky sú využitel'né ako podklad pre územno-plánovacie dokumentácie, alebo iné dokumentácie, ktoré sa zaoberajú kvalitou vegetačných plôch a ich funkciami v sídelných útvaroch.

Metodický prístup hodnotí vegetačné plochy v nasledovných oblastiach: kvalita vegetácie, dizajn, faktory prostredia, manažment a vybavenost'. V príspevku uvádzame hodnotenie z hl'adiska vykonávaného manažmentu a jeho vplyvu na mieru úžitku KES konkrétne na rekreáciu.

\section{Teoreticko-metodické východiská}

Navrhovaná metodika je nový prístup hodnotenia KES. Zamerali sme sa na hodnotenie plôch v urbanizovanom prostredí. V uvedenom metodickom prístupe hodnotíme vybrané vegetačné plochy na sídlisku Chrenová v Nitre. Tieto priestory považujeme za miesta, ktoré poskytujú obyvatel'om úžitky z hl'adiska KES. Konkrétne sa jedná o rekreáciu a vplyvu kvality priestoru na využívanie vol'ného času obyvatel'mi. Jeden $\mathrm{z}$ dôležitých aspektov plnenia rekreačných funkcií je kvalitný manažment prvkov vegetácie. Metodický prístup sme overili na ploche P1, ktorá sa nachádza na Chrenovej 1 - je to čast' sídliska Chrenová v Nitre. Lokalizácia $\mathrm{v}$ rámci mesta Nitra je znázornená na obr. 1. Chrenová sa nachádza v blízkosti centra mesta. Čast' sídliska je situovaná v kontakte s riekou Nitra. Plocha je pod starostlivost'ou mesta Nitra, konkrétne mestskej časti Chrenová 1.

Terénny prieskum sme robili v jarných a letných mesiacoch $\mathrm{v}$ troch fázach. V prvej fáze sme zmapovali územie, oboznámili sme sa so skutkovým stavom a následne zaznačili do mapového podkladu. V druhej fáze sme hodnotili vegetáciu a jej stav. S výsledku vyplýva, že na ploche prevládajú listnaté druhy 
javor horský (Acer pseudoplatanus), lipa malolistá (Tilia cordata), v menšom počte breza previsnutá. $Z$ ihličnatých druhov sa tu vo vel'kom počte nachádza druh duglaska tisolistá (Pseudotsuga menziesii). Esteticky hodnotná je skupina borovice lesnej (Pinus syslvestris) (obr. 2). Za negatívum považujeme dlhý rad druhu tuja západná (Thuja occidentalis) vysadených pri detskom ihrisku (obr. 3).

Obr. 1: Lokalizácia riešeného územia

Figure 1: Localization of the solved area

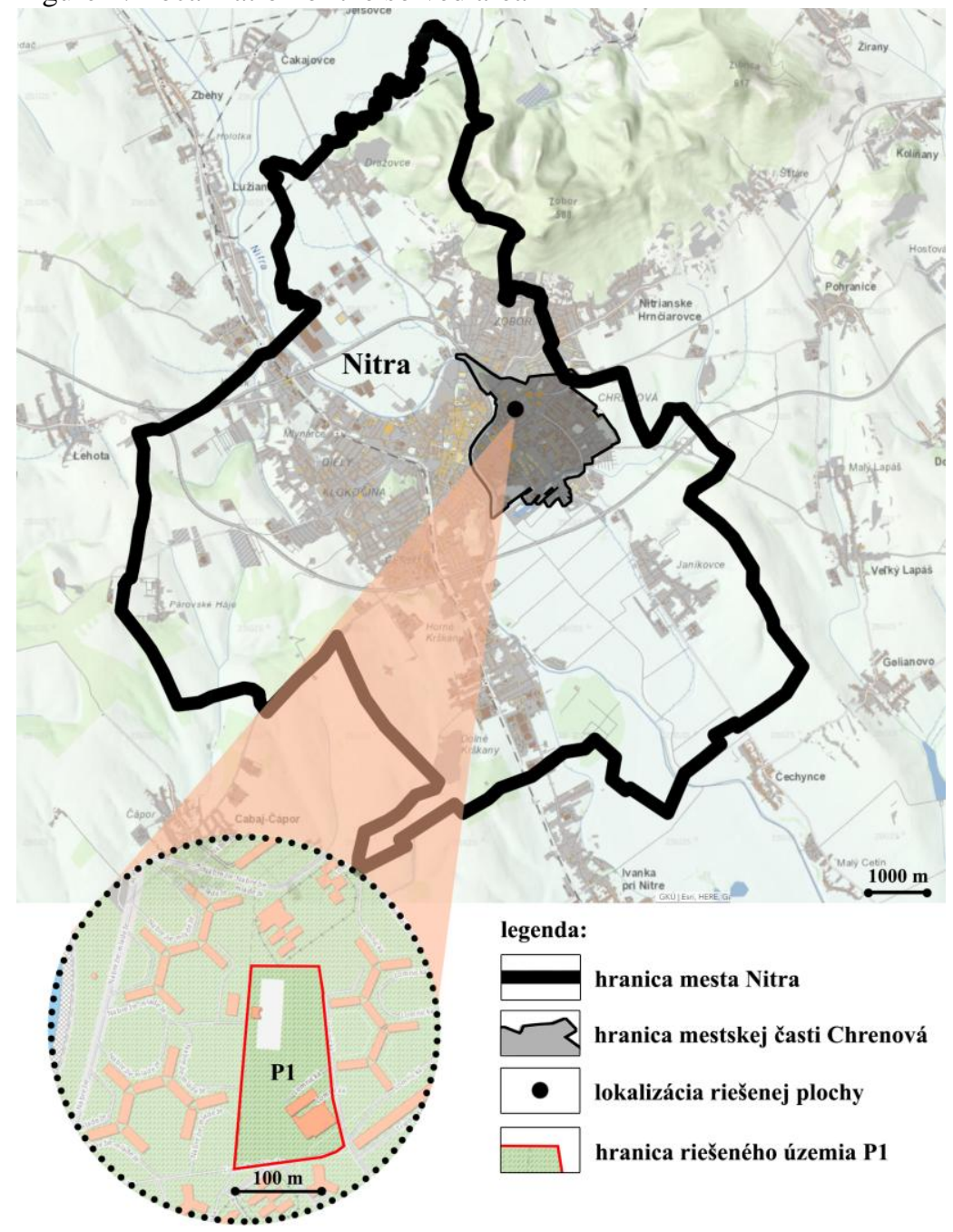


Obr. 2: Skupina Pinus syslvestris

Figure 2: Group of Pinus syslvestris

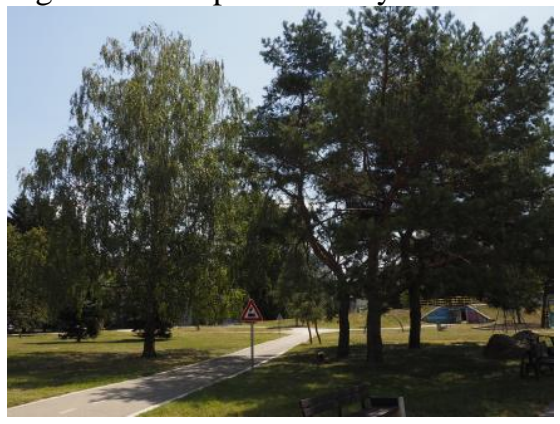

Obr. 3: Rad Thuja occidentalis

Figure 3: Series of Thuja occidentalis

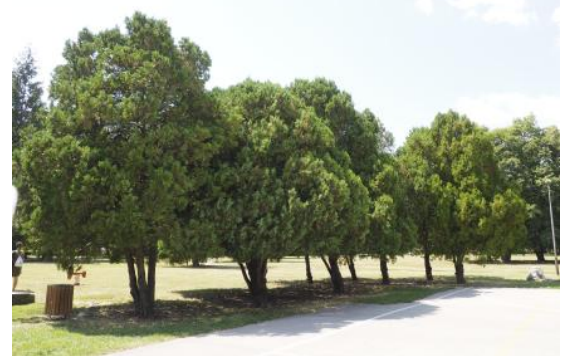

V tretej fáze výskumu sme hodnotili d'alšie prvky z metodiky, ktorej súčast'ou je aj hodnotenie manažmentu.

Sídlisko Chrenová od architekta Michaela Scheera je príkladom toho, ako kvalitná obytná čast', zapísaná do urbanisticko-architektonickej knihy UNESCO je plná stromov a má mnoho predpokladov na to, aby fungovala ako priestor pre l'udí, ktorí z nej budú mat' úžitok. Aj napriek rôznym negatívam predstavuje obytný súbor Chrenová kvalitnú čast' mesta, kde sa l'udia a jej obyvatelia s oblubou zhromažd’ujú a trávia vol'ný čas. Preto sme tento priestor vyhodnotili z pohl'adu poskytovania úžitkov KES a plnenia rekreačnej funkcie.

\section{Analýza manažmentu plochy}

Vegetácia sa nezaobíde bez odbornej starostlivosti. Hodnotenie manažmentu je dôležitým obrazom kvality prostredia. Čím lepšia starostlivost', tým vyššia kvalita vegetačnej plochy. Hodnotíme starostlivost' o stromy a kry , trávnik a kvetinové záhony.

\section{Stromy a kry}

Stromy a kry, ako základné stavebné prvky vegetačných plôch $\mathrm{k}$ tomu, aby plnili svoje funkcie, vyžadujú celoročnú odbornú starostlivost'. Je potrebné orezávat' suché konáre, vykonávat' zmladzovacie rezy, prípadné ošetrenie chorôb a mechanických poškodení. Dobrou starostlivost'ou sú stromy a kry schopné plnit' svoje funkcie a poskytovat' čo najlepšie úžitky pre obyvatel'ov. Starostlivost' hodnotíme v rozmedzí hodnôt $0-3$, kde 3 predstavuje najvyšší stupeň starostlivosti:

0 - plocha bez starostlivosti,

1 - orezávanie je nedostatočné, na ploche sú stromy so suchými konármi, dreviny bez zmladzovacích rezov,

2 - orezávanie stromov sa vykonáva $\mathrm{v}$ nevyhnutných prípadoch, 
zmladzovacie rezy sa vykonávajú nedostatočne, priestor je v dobrom stave,

3 - pravidelné orezávanie, čistenie, prebierka drevín, starostlivost’ je na dobrej úrovni.

\section{Trávnik}

Trávnik dotvára kompozíciu celého priestoru. Od jeho kvality záleží celkový vzhl'ad vegetačnej plochy. Pri starostlivosti je dôležité brat' do úvahy výšku kosenia, ponechania nekosených plôch pre opel'ovače, prípadne zavlažovanie $\mathrm{v}$ suchých ročných obdobiach. Trávnik hodnotíme číselnými hodnotami 0-3, kde 3 je najvyššia kvalita manažmentu trávnatej plochy:

0 - trávnik bez starostlivosti,

1 - trávnik je v zlom zdravotnom stave, kosenie sa robí nedostatočne alebo v nepravidelných intervaloch, plochy sú znečistené a zaburinené,

2 - trávnik je pravidelne kosený bez ohl'adu na počasie, môže sa stat' že pri vyšších teplotách je preschnutý, plochy sa čistia, starostlivost' bez osobitného prístupu $\mathrm{k}$ ploche,

3 - pravidelné kosenie rešpektujúce počasie a aktuálny stav (pri vysokých teplotách je trávnik menej kosený), trávnik je čistený, dôraz sa kladie na biodiverzitu a ponechávajú sa nekosené plochy pre opel'ovače.

\section{Kvetinové záhony}

Kvetinové záhony esteticky dotvárajú priestor a majú nezastupitel'nú funkciu v podpore biodiverzity $\mathrm{v}$ meste. Svojou premenlivost'ou v rôznych ročných obdobiach dopĺñajú aj ostatné kategórie hodnotenia ako napríklad farebnost', dizajn alebo kompozičné stvárnenie (Turanovičová, Rózová, 2017). Starostlivost' o záhony je náročná, ale je potrebná pre estetické pôsobenie aj niekol'ko rokov. Starostlivost' hodnotíme v rozmedzí číselných hodnôt 0-3, kde 3 je najlepšia starostlivost':

0 - záhony bez starostlivosti, alebo plocha bez kvetinových záhonov,

1 - záhony sú v zlom stave, zaburinenie presahuje 50\% záhonu, táto kategória predstavuje prestarnuté záhony,

2 - záhony sú odburiňované, nepravidelne hnojené, zostrihávanie je realizované jeden krát za rok,

3 - pravidelné odburiňovanie a hnojenie, jarná a jesenná údržba, zostrihávanie pod odborným dohladom.

\section{Priradenie miery úžitku ku kvalite vykonávaných opatrení manažmentu}

Analýza manažmentu je realizovaná pomocou pridelenia číselných hodnôt prvkom, na ktorých sa manažment vykonáva (stromy a kry, trávnik, kvetinové záhony). Ku kvalite vykonávaného manažmentu v jednotlivých parametroch (tab. 
2) priradíme mieru úžitku podl'a tab. 1. Číselnej hodnote 0 priradíme 0 bodov. Postupuje sa vzostupne. Vegetačná plocha môže získat' najviac 9 bodov a najmenej 0 .

Tab. 1: Pridelenie miery úžitku ku kvalite manažmentu

Table 1: Assigning quality of benefits to quality of management

\begin{tabular}{|c|c|}
\hline Kvalita manažmentu & Miera úžitkov (bodové hodnotenie) \\
\hline 0 & 0 \\
\hline 1 & 1 \\
\hline 2 & 2 \\
\hline 3 & 3 \\
\hline
\end{tabular}

Tab. 2: Kategórie miery úžitkov manažmentu na riešenej ploche

Table 2: Categories of benefits related management on the studied area

\begin{tabular}{|l|l|l|}
\hline \multicolumn{1}{|c|}{ Parametre } & $\begin{array}{c}\text { Kvalita vegetácie } \\
\text { (zaokrúhlený priemer) }\end{array}$ & $\begin{array}{c}\text { Miera úžitkov } \\
\text { (bodové hodnotenie) }\end{array}$ \\
\hline sadovnícka hodnota & & \\
\hline zdravotný stav & & \\
\hline kompozičná hodnota & & \\
\hline \multicolumn{2}{|c|}{ Spolu bodov } & \\
\hline \multicolumn{2}{|c|}{ Kategória miery úžitkov }
\end{tabular}

Kategórie miery úžitkov manažmentu pre rekreačnú ekosystémovú službu z hl'adiska kvality vykonávaného manažmentu na vegetačnej ploche:

4. 9-8 bodov - vysoký stupeň poskytovania úžitkov v rámci kultúrnych ES - manažment je vykonávaný vo všetkých kategóriách, stromy a kry sú ošetrované, trávnik kosený podl'a potreby a ohl'adu na počasie, kvetinové záhony sa v plnej miere prejavujú vo svojich vlastnostiach, všetky opatrenia sa vykonávajú odborne s ohl'adom na potreby prírodných prvkov,

3. 7-5 bodov - priemerný stupeň poskytovania úžitkov v rámci kultúrnych ES

- niektoré opatrenia môžu byt' vykonávané s nedostatkami, za nedostatky pokladáme vel’mi nízko kosený trávnik, ktorý v letných mesiacoch preschne, nepravidelná zálievka záhonov a pod.,

2. 4-3 bodov - nízky stupeň poskytovania úžitkov v rámci kultúrnych ES - manažment sa vykonáva nepravidelne a často bez odborného prístupu, stromy môžu byt' zle orezané, trávnik nízko kosený,

1. 2-0 body - nedostačujúci stupeň poskytovania úžitkov v rámci 
kultúrnych ES

- na ploche chýba starostlivost' o prvky vegetácie, ak sa vykonáva, tak vel'mi neodborne a nepravidelne.

\section{Výsledky}

\section{Charakteristika riešeného územia}

Vegetačná plocha P1 na Chrenovej 1 sa nachádza medzi ulicami L’udovíta Okánika a Lomnickou (obr. 1). Rozloha plochy je $26000 \mathrm{~m}^{2}$. Je centrálnou zhromažd'ovacou plochou. Lokalizovaná je v strede medzi obytnými súbormi. Je pomerne rušná a navštevovaná. Nachádza sa tu dopravné detské ihrisko, ktoré je centrálnym herným prvkom. Miesta na sedenie, chodníčky a pohostinstvo poskytuje možnosti na využívanie vol'ného času aj ostatným vekovým kategóriám.

Nachádza sa tu množstvo prevažne listnatých stromov. Plocha detského dopravného ihriska je betónová, čo je na úkor trávnatých plôch. Trávnaté plochy sa nachádzajú na okraji vegetačnej plochy. Nie sú dostatočne využívané.

\section{Analýza manažmentu vegetačnej plochy P1}

Vegetačná plocha P1, Chrenová 1 je z hl'adiska manažmentu pravidelne udržiavaná. Stromy a kry sú bez výrazných suchých konárov, trávnik je pravidelne kosený. Trávnik je $\mathrm{v}$ letných mesiacoch príliš preschnutý, čo je výsledok neodborného kosenia. Kvetinové výsadby sa nenachádzajú.

\section{Stromy a kry:}

hodnota 3 - na ploche je vykonávané pravidelné orezávanie suchých konárov, prostredie je bezpečné, stromy sú odborne ošetrované. Listnaté stromy (obr. 4) sú v dobrom zdravotnom stave čo je výsledok dobrého manažmentu, skupiny ihličnatých stromov (obr. 5) nie sú prehustené a vytvárajú príjemné zatienené miesta.

\section{Trávnik:}

hodnota 2 - pravidelne kosený trávnik, v letných mesiacoch je preschnutý (obr. 6) a zaburinený (obr. 7) čo je výsledkom nevhodného manažmentu, kosenie je potrebné vykonávat' s ohl'adom na počasie, kvalita vykonávaného manažmentu je priemerná.

\section{Kvetinové záhony:}

hodnota 0 - nenachádzame tu žiadne kvetinové záhony. 
Obr. 4: Skupina listnatých stromov s vel'mi dobrou starostlivost'ou

Figure 4: Group of deciduous trees

with very good management

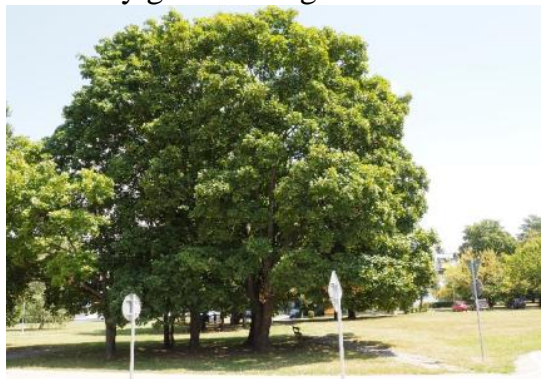

Obr. 6: Preschnutý trávnik

Figure 6: Dry lawn

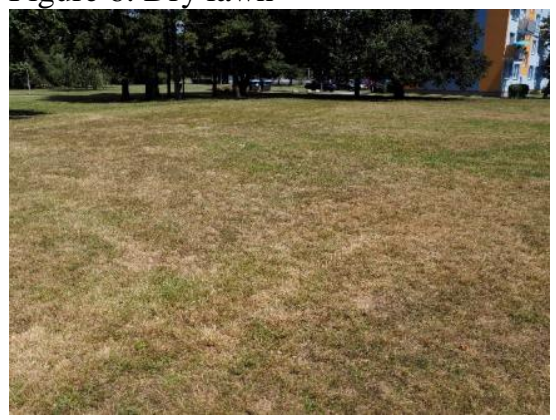

Obr. 5: Skupina ihličnatých stromov s vel'mi dobrou starostlivost'ou

Figure 5: Group of coniferous trees

with very good management

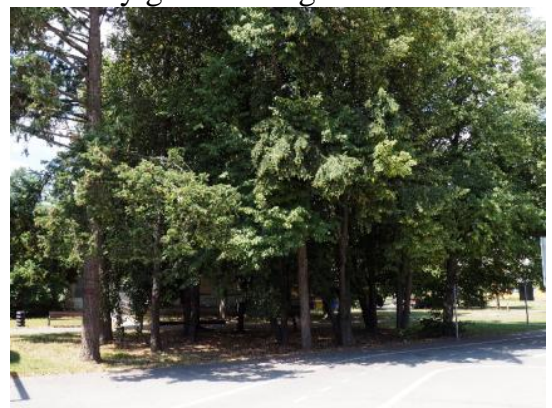

Obr. 7: Zaburinený trávnik

Figure 7: Weeded lawn

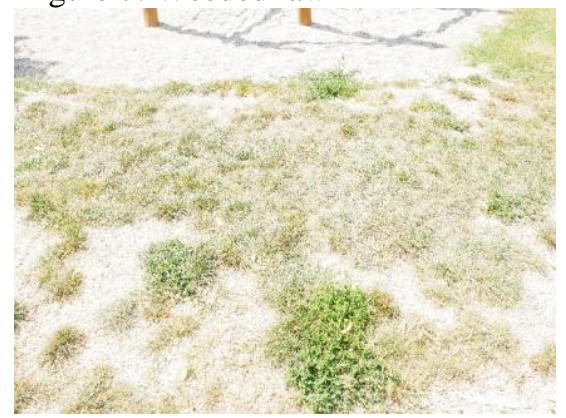

\section{Hodnotenie manažmentu a stupeň poskytovania úžitkov v rámci rekreácie na riešenej ploche $\mathbf{P 1}$}

Hodnotenie na základe tab. 3, zaradilo plochu do kategórie 3 - priemerný stupeň poskytovania úžitkov $\mathrm{v}$ rámci KES. Na ploche sú vykonávané základné manažmentové opatrenia, ktoré plochu zarad’ujú do kategórie, ktorá poskytuje priemerné služby. Priestor je vd’aka pravidelnému orezávaniu suchých konárov bezpečný. Trávnik sa dá využívat' pre rôzne aktivity. Nedostatkom je kosenie trávnika bez ohl'adu na ročné obdobie, čo spôsobuje v letných mesiacoch preschnutie. Chýbajúce kvetinové záhony na ploche negatívne ovplyvňujú celkové estetické pôsobenie prostredia. Ich absencia ovplyvňuje hodnotenie nakol'ko $\mathrm{v}$ tejto kategórii plocha dostala 0 bodov. 
Tab. 3: Kategórie miery úžitkov manažmentu na ploche P1

Table 3: Categories of benefits related management on the P1 area

\begin{tabular}{|l|c|c|}
\hline \multicolumn{1}{|c|}{ Prvky vegetácie } & Kvalita manažmentu & $\begin{array}{c}\text { Miera úžitkov } \\
\text { (bodové hodnotenie) }\end{array}$ \\
\hline stromy a kry & 3 & 3 \\
\hline trávnik & 2 & 2 \\
\hline kvetinové záhony & 0 & 0 \\
\hline \multicolumn{2}{|c|}{ Spolu bodov } & 5 \\
\hline \multicolumn{2}{|c|}{ Kategória miery úžitkov } & 3 \\
\hline
\end{tabular}

\section{Záver}

Riešená plocha P1 na Chrenovej 1 v Nitre má množstvo stromov, krov a trávnatých plôch. Hodnotenie kvality manažmentu zaradilo plochu do kategórie priemerného stupňa poskytovania úžitkov v rámci kultúrnych ekosystémových služieb. Prostredie je bezpečné a čisté a vegetácia je udržiavaná. Kvalita manažmentových opatrení sa pozitívne odráža na vitalite stromov, krov a trávnika. Nachádzame stromy v dobrej kondícii.

$\mathrm{Na}$ zlepšenie funkcie a poskytovania čo najväčšieho úžitku, by bolo potrebné vhodnejšie ošetrovat' trávnik na odbornej úrovni, aby aj počas letných dní poskytoval úžitok. Pod pojmom úžitok rozumieme situáciu, kedy sú vegetačné prvky v dobrej kondícii, pohyb v ich blízkosti je bezpečný, nenachádzajú sa tu staré suché konáre, trávnik je vhodný na sedenie, piknik a hru detí. Je potrebné, aby priestor poskytoval možnosti na rekreáciu, oddych, stretávanie sa s l'ud'mi, športové aktivity a d'alšie.

Úroveň kvality manažmentu je jedna z oblastí, ktoré sú potrebné na dosiahnutie kvalitného prostredia vhodného na rekreačné a oddychové aktivity.

Vel'ké množstvo vegetačných plôch na sídliskách nespĺñajú potrebné kvality. Ludia sa aj napriek tomu na vegetačných plochách zdržiavajú. Zvýšením ich kvality by stúpol počet návštevníkov, vd'aka čomu by sa budovali medzil'udské a susedské vzt'ahy, l'udia by mali šancu byt' viac v prírode, športovat' a iné. Výsledky je možné využit' v územno-plánovacích dokumentáciách alebo iných dokumentoch, ktoré riešia kvalitu vegetácie v urbanizovanom území nie len vo vzt’ahu k rekreácii v rámci KES.

\section{Pod'akovanie}

Príspevok bol spracovaný v rámci projektu VEGA 1/0496/16 Hodnotenie prírodného kapitálu, biodiverzity a ekosystémových služieb na Slovensku - základ pre uplatňovanie integrovanej environmentálnej politiky $v$ praxi. 


\section{Literatúra}

CHAN, K. M. A. - GOLDSTEIN, J. - SATTERFIELD, T. - HANNAHS, N. KIKILOI, K. - NAIDOO, R. - VADEBONCOEUR, N. - WOODSIDE, U. 2011. Cultural services and non-use values. In Kareiva, P., Tallis, H., Ricketts, T. H., Daily, G. C., Polasky, S. (eds.) Natural Capital: Theory and Practice of Mapping Ecosystem Services. Oxford: Oxford University Press, pp. 206-228.

DOVER, J.W. 2015. Green Infrastructure, Incorporating plants ad enhancing biodiversity in buildings and urban environments. Abingdon: Routledge, 2015. 337 s. ISBN 978-0-415-52123-9.

HORKÁ, J. - DROCHYTKOVÁ, J. - NEPUSTILOVÁ, K. 2014. Participace verějnosti jako šance pro funkční veřejný prostor - Nová zeleň pod Starou branou. In Zahrada-park-krajina. ISSN 1211-1678, 2014, roč. 24, č. 4, s. 1821.

LADLLE, P. - PROVENDIER, D. - COLSON F. - SALANIÉ, J. 2013. The benefits of urban vegetation: a study of scientific research and method of analysis. [online]. Angers: Plante \& Cité, 2013. 31 p. Dostupné na internete: <https://www.plante-et-cite.fr/data/beneveg_english_bd.pdf>

MAES, J. et al. 2013. Mapping and assessment of ecosystems and their service: An analytical framework for ecosystem assessment under Action 5 of the EU Biodiversity Strategy to 2020. Luxembourg: Publications Office of the European Union, 2013. $60 \mathrm{p}$.

PISCOVÁ, V. a kol. 2018. Využivanie vysokohorskej krajiny a jeho dôsledky na zmenu prostredia. Bratislava: Veda, 2018. 250 s. ISBN 978-80-224-1585-9.

PLIENINGER, T. et al. 2013. Assessing, mapping, and quantifying cultural ecosystemservices at community level. In Land Use Policy. vol. 33, pp.118129.

SUPUKA, J. - FERIANCOVÁ, L. - SCHLAMPOVÁ, T. - JANČURA, P. 2004. Krajinárska tvorba. Nitra: Slovenská pol’nohospodárska univerzita, 2004. 256 s. ISBN 80-8069-334-X.

TURANOVIČOVÁ, M. - RÓZOVÁ, Z. 2017. Metodické východiská hodnotenia kultúrnych ekosystémových služieb v urbanizovanom prostredí. In Životné prostredie. ISSN 0044-4863, 2017, roč. 51, č. 4, s. 232-239.

\section{EVALUATION OF THE MANAGEMENT INTERVETIONS AND THEIR IMPACT ON CULTURAL ECOSYSTEM SERVICES}

\section{Summary}

The public space used for recreation should be a place that has functional greenery, furniture, playgrounds and leisure. Public spaces provide the inhabitants with certain benefits and benefits that we can use to refer to cultural (recreational) 
ecosystem services. A particular part of public spaces are vegetation areas that combine different functions and provide benefits. The quality of urban vegetation areas affects the quality of life of the population and daily recreation. That is why we have focused on creating an appropriate methodical approach that assesses the current state of affairs and determines the level of benefits of vegetation areas for recreation. The method approach is applicable to all settlement units and can be used after the modifications to assess the various functions that vegetation areas can perform within the cultural ecosystem services.

We have verified the methodical approach on the area of Chrenová in Nitra, which provides benefits to residents within recreational and leisure activities. Chrenová has 4 parts and the area $\mathrm{P} 1$ on which the research is carried out is the central vegetation area of the settlement Chrenová 1 . In the paper we present a part of a methodical approach focused on the management of vegetation areas. Under management in this post, we mean year-round professional care (trimming of branches, treatment of diseased parts of trees, shrinking shrubs). This management is performed on vegetation elements (trees and shrubs, lawns and flower beds).

The evaluation is based on the assignment of numeric value to elements of vegetation based on the quality of the management. We have a detailed field research and site-based vegetation assessment. Evaluation was performed during spring and summer months, when caring for vegetation is the most frequent. With proper autumn management, vegetation remains in good condition until spring, as seen in the early spring surveys.

Management measures are carried out on all existing elements of vegetation. Trees care is good. All trees are in good condition. The space is safe due to the regular trimming of dry blocks, which positively affects the recreation on the ground. The biggest deficiency is lawn, which is very dry in the summer months. In this case, we consider management to be incompetent. Irrigation is also a good option. Dry lawns deplete the area of recreational benefits for people which would provide good health. The absence of flower beds negatively affects the assessment of the area. The rating ranked area in the category of the average degree of provision of benefits within the framework of cultural ecosystem services.

The existence of vegetation in cities is very important. It enriches life from different perspectives. In the paper, we presented the proposed methodical procedure for assessing the quality of vegetation areas in terms of management. The results can be used in land-use planning documents or other documents that address the quality of vegetation in the urbanized area not only in relation to cultural ecosystem servicis and recreation. The overall quality of the vegetation area is a combination of the evaluation also in the other categories not mentioned in the contribution. 


\section{Ing. Martina Turanovičová}

Univerzita Konštantína Filozofa v Nitre

Trieda A. Hlinku 1, 94974 Nitra

E-mail: martina.turanovicova@ukf.sk

Prof. Ing. Zdenka Rózová, CSc.

Univerzita Konštantína Filozofa v Nitre

Trieda A. Hlinku 1, 94974 Nitra

E-mail: zrozova@ukf.sk 